\title{
ДО ПИТАННЯ ОЦІНКИ ЗНАЧЕННЯ ГІПЕРУРИКЕМІЇ З ПОЗИЦЙ ПРИНАЛЕЖНОСТІ ДО МЕТАБОЛІЧНОГО СИНДРОМУ
}

\author{
А.О. Черняєва ${ }^{1,2}$ \\ ${ }^{1}$ Державна установа «Інститут проблем ендокринної патології ім.В.Я.Данилевського Національної \\ академії медичних наук України», відділ клінічної ендокринологї, м. Харків, Україна; \\ ${ }^{2}$ Харківська медична академія післядипломної освіти Міністерства охорони здоров'я України, \\ кафедра ендокринології та дитячої ендокринології, м. Харків, Україна, \\ ORCID ID: 0000-0002-2812-3323, e-mail: annakholodnaja2008@gmail.com
}

Резюме. Цілі: аналіз зв’язку гіперурикемії (ГУ) з компонентами метаболічного синдрому (МС) у випадковій популяційній вибірці.

Методи. Група з 727 обстежених сформована методом випадкової вибірки з числа робочих і службовців промислового підприємства. Вік обстежених від 18 до 65 років. Проводили діагностику МС та порушень глюкозного гомеостазу (ПГГ), клініко-біохімічне дослідження. Інсулінорезистентність оцінювали за індексом HOMA2_IR. Статистичний аналіз проводили з використанням "Statgraphics Plus for Windows 3.0».

Результати. ГУ діагностовано у 16,2 \% осіб. Встановлено, що у осіб із ГУ підвищується вірогідність діагностики ПГГ у 5,1 разу, цукрового діабету (ЦД) 2 типу в 3,7 разу, ожиріння в 2,9 разу, артеріальної гіпертензії (АГ) в 2,3 разу і дисліпідемії в 1,7 разу відповідно. Визначено, що практично кожний 2-й випадок ГУ у випадковій популяційній вибірці асоціюється як мінімум ще з 2-ма компонентами МС (АГ + ожиріння), у кожному 4-му випадку - 3 3-ма компонентами (АГ + ожиріння + дисліпідемія), в кожному 8-му випадку - 3 4-ма компонентами (АГ + ожиріння + дисліпідемія + ПГГ). Встановлено, що кожний 4-й представник випадкової популяційної вибірки, у якого було діагностовано порушення толерантності до глюкози (ПТГ) і ЦД 2 типу, має «повний» $\mathrm{MC}$; вірогідність діагностики МС у осіб з ПГГ зростає в 10 разів порівняно з популяцією.

Висновки. Якщо верифікацію «повного» МС не обмежувати обов'язковим включенням до його складу ГУ, частота діагностики в одного представника випадкової популяційної вибірки квартету симптомів (ожиріння $+\mathrm{A} \Gamma+$ дисліпідемія + гіперінсулінемія) зростає вдвічі і складає вже 4 \% від усієї вибірки. За цієї умови в кожного 2-го представника вищезазначеної вибірки з ПТГ діагностують «повний» МС.

Ключові слова: гіперурикемія, метаболічний синдром, порушення глюкозного гомеостазу, цукровий діабет 2 типу.

Вступ. Метаболічний синдром (МС) - це кластер факторів ризику кардіоваскулярних захворювань, до яких відносяться вісцеральне ожиріння, артеріальна гіпертензія (АГ), дисліпідемія і порушення толерантності до глюкози (ПТГ). В 1999 році ВООЗ вперше було запропоновано визначення і діагностичні критерії МC [1], які пізніше були переглянуті National Cholesterol Education Program's Adult Treatment Panel III (NCEP/ATP III) [2] i International Diabetes Federation (IDF) [3]. Ні в одних 3 наявних версій рекомендацій щодо діагностики МC гіперурикемію (ГУ) не визнано критерієм МС, хоча поєднання МС і ГУ є досить частим явищем $[4,5]$. Така позиція грунтується на результатах деяких досліджень, у т.ч. Фрамінгемського, у яких не було виявлено прямого зв'язку між концентрацією сечової кислоти (СК) і серцево-судинними захворюваннями (СС3) після модифікації інших факторів ризику, таких як ожиріння і АГ [6]. У той же час з урахуванням результатів цілої низки досліджень можна із певністю констатувати, що рівень урикемії корелює з ризиком МC, ступенем ожиріння, гіперінсулінемією, рівнем тригліцеридемії і глікемії, тобто клініко-біохімічними параметрами, що відображають стан інсулінорезистентності (IP) [7].
Обгрунтування дослідження. 3 урахуванням основних пріоритетів сучасної медицини по боротьбі з серцево-судинними захворюваннями актуальними залишаються дослідження про вивчення зв'язків між ГУ і АГ, хронічною хворобою нирок i кардіоваскулярною патологією. На підставі огляду даних NHANES III H.K. Choi і співавт. встановили, що частота MC у хворих на подагру становить 62,8 \% i тільки 25,4 \% у хворих без подагри [8]. Показано також, що частота IP у хворих на подагру на $35 \%$ вище, ніж у хворих без порушень пуринового обміну [9]. Окрім зв'язку між МС і подагрою, в останнє десятиріччя широко вивчається зв'язок між ГУ і окремими компонентами МС. Так, за останні роки встановлено роль ГУ як незалежного предиктора цукрового діабету 2 типу (ЦД 2 типу) [10]. У свою чергу, експериментальні дослідження демонструють роль ГУ в формуванні IP, жирової хвороби печінки та дисліпідемії у фруктозозалежних і фруктозонезалежних моделях МС [11]. 3 огляду на це зниження рівня урикемії може виявитися простим і недорогим способом профілактики ЦД 2 типу і сприяти уповільненню пандемії цього неінфекційного захворювання.

Мета дослідження: проведення аналізу зв'язку гіперурикемії з компонентами метаболічного 
синдрому у випадковій популяційній вибірці (за епідеміологічними критеріями).

Матеріали і методи. Група обстежених сформована за загальноприйнятими епідеміологічними підходами методом випадкової вибірки з числа робочих і службовців промислового підприємства ПАТ «Новокраматорський машинобудівний завод». Згідно 3 договорами №1/17-К від 03.04.2017, №2/17-К від 17.11.2017, №1/18-К від 19.02.2018 і №1/19-К від 06.02.2019, укладеними між ДУ «Інститут проблем ендокринної патології ім. В.Я. Данилевського НАМН України» і первинною профспілковою організацією підприємства, обстежено 727 осіб.

Вік обстежених - від 18 до 65 років, в середньому $(38,13 \pm 5,1)$ років. За статтю обстежені розподілялися наступним чином: 457 чоловіків і 270 жінок.

Наявність та ступінь ожиріння визначали за індексом маси тіла (IMT), згідно з критеріями ВОO3 (2000) [12]. Визначення обводу талії (ОТ) (см) проводили у вертикальному положенні хворого на середині відстані між нижнім краєм грудної клітки і гребенем здохвинної кістки по середньопахвинній лінії.

MC діагностували згідно з спільною проміжною заявою IDF, NHLBI, AHA, WHF, IAS i IASO [13] за наявності хоча б трьох з п'яти компонентів: 1) абдомінальне ожиріння (ОТ у чоловіків $>90 \mathrm{~cm}$, у жінок $>80$ см за критеріями IDF і WHO); 2) рівень тригліцеридів (ТГ) >1,7 ммоль/л; 3) рівень холестерину ліпопротеїнів високої щільності (ХС-ЛПВЩ) $<$ 1,03 ммоль/л у чоловіків і < 1,3 ммоль/л у жінок; 4) систолічний артеріальний тиск (САТ) $\geq 130$ мм.рт.ст., діастолічний артеріальний тиск (ДАТ) $\geq 85$ мм. рт. ст.; 5) глікемія натще (Глю $) \geq 5,56$ ммоль/л.

Оцінку стану глюкозного гомеостазу здійснювали згідно 3 рекомендаціями RSSDI-ESI Consensus group 2020 p. [14]. Рівень Глю хвилині (Глю120) перорального тесту толерантності до глюкози визначали в плазмі венозної крові глюкозооксидазним методом на аналізаторі "Biosen C-line" (EKF, Німеччина). Тест проводили особам, у яких було діагностовано гіперглікемію натще $(\Gamma Н)$.

Зразки венозної крові забирали у кожної особи після 12-годинного голодування. Рівень імунореактивного інсуліну (IPI) визначали імунохемілюмінесцентним методом 3 використанням набору Insulin Elisa, («ELISA» DRG Diagnostics, США). Ступень виразності IP оцінювали за індексом HOMA2 IR (у.о), який розраховували за допомогою НОМА Calculator v2.2 для вільного користування [15].

Дослідження рівня загального холестерину (ЗХС), ТГ, ХС-ЛПВЩ проводили ферментативним колориметричним методом: при визначенні $3 \mathrm{XC}$ та ТГ за допомогою наборів фірми «СпайнЛаб» (Харків, Україна) з використанням аналізатора Флюорат02-АВЛФ-Т, при визначенні ХС-ЛПВЩ - із використанням набору фірми ЗАТ «СпайнЛаб» (Харків, Україна). Рівні холестерину ліпопротеїдів низької щільності (ХС-ЛПНЩ), холестерину ліпопротеїдів дуже низької щільності (ХС-ЛПДНЩ) та коефіцієнт атерогенності (КА) обчислювали розрахунковим методом за загальноприйнятими формулами [16].
Концентрацію СК у крові і сечі визначали колориметричним методом за допомогою набору реагентів «Спайн Лаб, UricasePOD» (Україна).

Рівень артеріального тиску (АТ) вимірювали на плечовій частині лівої верхньої кінцівки на рівні серця за допомогою автоматичного сфігмоманометра (OMRON Corporation, Kyoto, Japan) з манжетою відповідного розміру. Вимірювання АТ проводили після 5-10 хв перебування хворого в стані спокою в положенні сидячи. Рівень САТ і ДАТ визначали як середнє двох послідовних вимірювань. АГ діагностували за рівня АТ >140/90 мм. рт. ст. [17].

Статистичний аналіз отриманих даних проведено за програмним комплексом "Statgraphics Plus for Windows 3.0» (Manugistic Inc. USA). Нормальність розподілу змінних визначали за допомогою тесту Шапіро-Уілка. Для порівняння парних перемінних у групах з нормальним розподілом змінних застосовували критерій Уілкоксона-Манна-Уітні. Для статистичної оцінки розбіжностей між емпіричними і теоретичними частотами варіаційного ряду застосовували критерій «хі-квадрат» $\left(\chi^{2}\right)$ з поправкою Yates. Для виявлення зв'язку між клінічними, біохімічними $\mathrm{i}$ гормональними показниками 3 нормальним розподілом перемінних використовували регресійний аналіз. Для вимірювання щільності зв'язку між ознаками обчислювали коефіцієнт асоціації (Ка) за К. Пірсоном. Перевірка нульових гіпотез проведена на рівні значущості $\mathrm{P} \leq 0,05$. Отримані результати представлено в таблицях у вигляді $\overline{\mathrm{X}} \pm \mathrm{s} ; \overline{\mathrm{X}} \pm \mathrm{s} \overline{\mathrm{X}}$, де $\overline{\mathrm{X}}-$ середнє арифметичне, $\mathrm{s}$ - стандартне відхилення, $\mathrm{s} \overline{\mathrm{X}}$ - середне відхилення.

Результати дослідження. ГУ діагностовано у 118 (16,2\%) осіб у випадковій статистичній вибірці.

Порушення глюкозного гомеостазу (ПГГ) виявили у 76 обстежених (10,5\%): ЦД 2 типу - у 22 (3,03\%), ПТГ - у 47 (6,5\%), ГН - у 7 (0,96 \%) відповідно. 322 хворих на ЦД 2 типу у восьми захворювання було діагностовано до проведення дослідження (у трьох хворих - легка форма, у п'яти - середнього ступеня важкості). ПГГ було діагностовано у кожного десятого обстеженого, а на кожний випадок ЦД 2 типу, який було діагностовано раніше, припадало близько трьох випадків ЦД 2 типу de novo (співвідношення 1:2,75), що обгрунтовує доцільність більш активного скринінгу населення на Цд 2 типу. Гіперінсулінемію діагностовано у 52,6\% обстежених 3 ПГГ $(\mathrm{n}=40)$ і у $22,1 \%(\mathrm{n}=161)$ без ПГГ. Ожиріння виявлено у 276 обстежених, що становило $37,9 \%$. Розподіл обстежених $з$ урахуванням ступеня ожиріння: ожиріння 1 ступеня $(\mathrm{n}=175)$ у $24,1 \%$, ожиріння 2 ступеня $(\mathrm{n}=101)$ у $13,9 \%$. Частота дисліпідемії у випадковій популяційній вибірці становила 18,02 \% $(\mathrm{n}=131)$. Виявлені порушення були представлені переважно дисліпідемією IV типу $(\mathrm{n}=86)$ у $11,8 \%$ обстежених, IIa типу $(n=35)$ у 4,81 \% і ІІб типу $(n=10)$ у 1,38\%. АГ діагностовано у 305 (41,9\%) осіб. Рівні САД і ДАД у 232 (31,9\%) обстежених відповідали критеріям граничної АГ, у 73 (10,4 \%) обстежених $\mathrm{A} \Gamma$.

На переважно метаболічний генез ГУ у обстежених випадкової популяційної вибірки вказує 
Таблиця 1

Клініко-лабораторні показники у випадковій популяційній вибірці з урахуванням рівня урикеміі

\begin{tabular}{|c|c|c|c|}
\hline Показник & Особи без ГУ $(\mathrm{n}=209)$ & $\begin{array}{c}\text { Особи з ГУ } \\
(\mathrm{n}=118)\end{array}$ & $\mathrm{P}$ \\
\hline 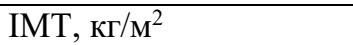 & $25,68 \pm 4,55$ & $32,4 \pm 6,01$ & $<0,001$ \\
\hline OT, см & $87,3 \pm 16,74$ & $100,2 \pm 13,8$ & $<0,001$ \\
\hline CAT, мм.рт.ст. & $130,2 \pm 1,4$ & $138,6 \pm 3,6$ & $<0,01$ \\
\hline ДАТ, мм.рт.ст. & $83,6 \pm 0,8$ & $89,2 \pm 1,4$ & $<0,01$ \\
\hline Глю, ммоль/л & $5,46 \pm 0,12$ & $7,85 \pm 0,69$ & $<0,01$ \\
\hline IPI, мкОд/мл & $18,02 \pm 8,83$ & $25,36 \pm 7,23$ & $<0,05$ \\
\hline HOMA2_IR, y.o & $2,37 \pm 1,12$ & $3,69 \pm 1,39$ & $<0,01$ \\
\hline ХС, ммоль/л & $5,09 \pm 0,77$ & $6,01 \pm 1,28$ & $<0,01$ \\
\hline ХС-ЛПВЩ, ммоль/л & $1,36 \pm 0,32$ & $1,12 \pm 0,24$ & $<0,02$ \\
\hline ТГ, ммоль/л & $1,11 \pm 0,34$ & $2,06 \pm 0,52$ & $<0,0001$ \\
\hline ХС-ЛПНЩ, ммоль/л & $3,06 \pm 0,12$ & $3,47 \pm 0,14$ & $<0,001$ \\
\hline ХС-ЛПДНЩ, ммоль/л & $0,2 \pm 0,01$ & $0,3 \pm 0,03$ & $<0,001$ \\
\hline KA, y.o & $2,67 \pm 0,06$ & $3,42 \pm 0,23$ & $<0,05$ \\
\hline СК в крові, мкмоль/л & $282,6 \pm 2,8$ & $418,0 \pm 8,2$ & $<0,001$ \\
\hline
\end{tabular}

Встановлено, що ожиріння, дисліпідемія, АГ, гіперінсулінемія і IP асоційовані з ГУ і без обов'язкової присутності ПГГ, тому ГУ може бути пов'язана не стільки із ПГГ, скільки обумовлена наявністю інших компонентів МС. Серед компонентів МС деякі автори особливе значення в опосередкованому зв’язку ГУ з ЦД 2 типу надають ожирінню [18, 19]. Якщо порівнювати частоту окремих компонентів МС за ГУ, то найбільш часто зустрічалися ожиріння $(63,6 \%)$ і підвищений АТ (66,1%) (табл. 2). Що стосується ПГГ, то їх представництво в групі обстежених з ГУ виявилося досить незначним (37,3\%).

Таблиця 2

Аналіз частоти компонентів МС у досліджуваних з урахуванням рівня урикемії

\begin{tabular}{|c|c|c|c|c|}
\hline Патологічний стан & $\begin{array}{c}\text { Особи з ГУ } \\
(\mathrm{n}=118)\end{array}$ & $\begin{array}{c}\text { Особи без ГУ } \\
(\mathrm{n}=609)\end{array}$ & $\begin{array}{c}\text { Значення критерію } \\
\chi^{2} \\
\end{array}$ & $\mathrm{P}$ \\
\hline Ожиріння: & $63,6 \%$ & $33,0 \%$ & 37,9 & 0,001 \\
\hline І ступеня & $34,7 \%$ & $22,0 \%$ & 8,09 & 0,005 \\
\hline II ступеня & $28,8 \%$ & $11,0 \%$ & 24,75 & 0,001 \\
\hline Підвищений АТ & $66,1 \%$ & $37,3 \%$ & 32,56 & 0,001 \\
\hline Високий нормальний АТ & $39,8 \%$ & $26,3 \%$ & 8,27 & 0,005 \\
\hline $\mathrm{A} \Gamma$ & $26,3 \%$ & $11,0 \%$ & 22,18 & 0,001 \\
\hline ПГГ: & $37,3 \%$ & $5,3 \%$ & 104,96 & 0,001 \\
\hline$\Gamma \mathrm{H}$ & $4,2 \%$ & $0,3 \%$ & 12,0 & 0,001 \\
\hline ПТГ & $21,2 \%$ & $3,6 \%$ & 47,62 & 0,001 \\
\hline ЦД 2 типу de novo $(\mathrm{n}=14)$ & $6,8 \%$ & $0,99 \%$ & 14,64 & 0,001 \\
\hline Дисліпідемія: & $27,1 \%$ & $16,3 \%$ & 7,18 & 0,008 \\
\hline IІа тип & $6,8 \%$ & $4,1 \%$ & 1,07 & 0,3 \\
\hline ІІб тип & $2,5 \%$ & $1,3 \%$ & 0,35 & 0,56 \\
\hline IV тип & $18,6 \%$ & $10,8 \%$ & 4,95 & 0,027 \\
\hline
\end{tabular}

Проте, для того щоб оцінити щільність зв'язку ГУ з іншими компонентами МС, не достатньо оцінки їх частоти, а важливо також з'ясувати, як ГУ підвищує вірогідність появи кожного конкретного компонента МС. Тобто чим значуще ГУ підвищує відносний ризик виникнення окремих компонентів MC, тим вагоміше має бути іiі значення для них як фактору ризику. Адже ожиріння і АГ, частота яких була значуще більш висока в групі обстежених з ГУ, були присутні і у осіб без ГУ (див. табл. 2). Встановлено, що за ГУ, у першу чергу, підвищується вірогідність діагностики ПГГ в 5,1 разу $(95 \%$ CI $(3,82-6,79)$ в цілому і ЦД 2 типу - в 3,7 разу (95 \% СІ $(2,28-6,02)$, далі ожиріння в 2,9 разу (95 \% CI (2,02-4,02), АГ в 2,3 разу $(95 \%$ CI $(1,61-3,25)$ і дисліпідемії в 1,7 разу (95\% CI $(1,18-2,42)$ відповідно. У дослідженні, в якому взяло участь 5012 дорослих молодого віку, показано, що ГУ підвищує ризик ШД в 1,87 разу і в 1,36 разу IP [20]. При цьому рівень урикемії не залежав від концентрації IPI в плазмі, що дозволило визнати ГУ незалежним предиктором IP і ЦД.

На підставі розрахунку Ка ГУ з основними компонентами МС, встановлено, що серед компонентів МС значення ГУ як фактора ризику є найбільш вагомим для ПГГ $(\mathrm{Ka}=0,64)$ (рис. 1). Встановлена щільність зв'язку ГУ з іншими компонентами МС 
дозволяє розглядати останню в якості повноправного компонента МС в популяції.
Встановлено, що практично кожний другий випадок ГУ сполучається 3 як мінімум ще 3 двома компонентами МС - АГ або ожирінням (табл. 3).

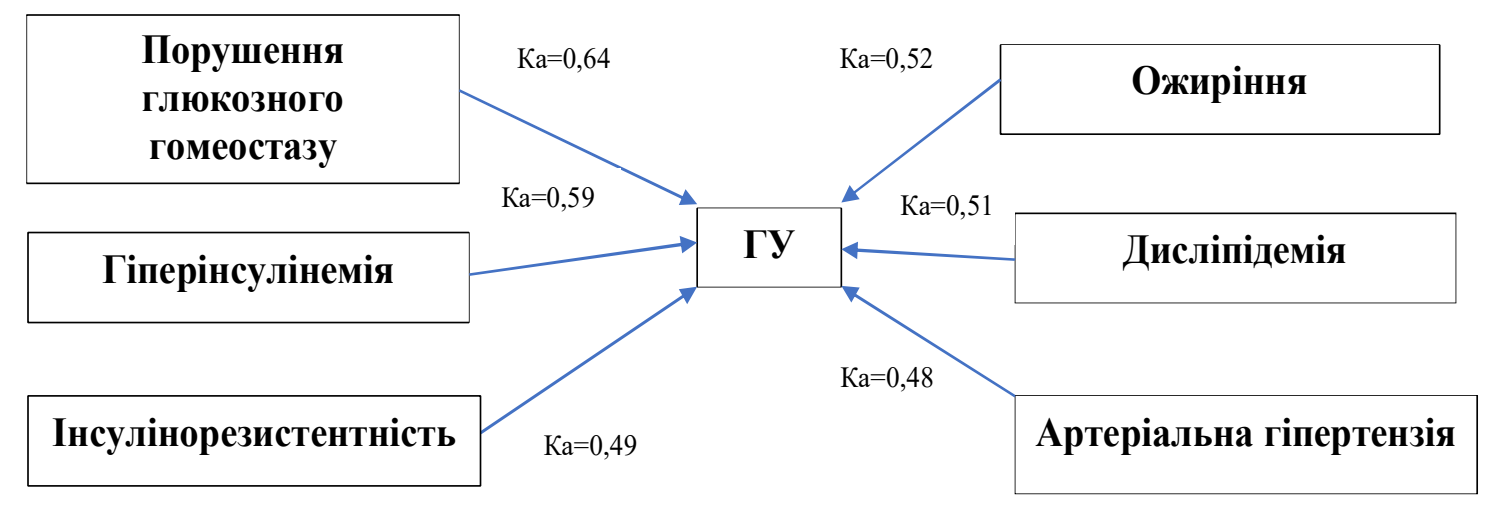

Рис. 1. Компоненти МС, асоційовані з ГУ у випадковій популяційній вибірці

Таблиця 3

Частота компонентів МС у випадковій популяційній вибірці з урахуванням рівня урикемії

\begin{tabular}{|l|c|c|}
\hline Компоненти МС & $\begin{array}{c}\text { Кількість обстежених (n)/\% від всіх } \\
\text { випадків ГУ }\end{array}$ & \begin{tabular}{c} 
\% у випадковій популяційній вибірці \\
\hline ГУ+4 компонента
\end{tabular} \\
\hline ГУ+3 компонента & $15 / 12,7$ & 2,1 \\
\hline ГУ+2 компонента & $31 / 26,3$ & 4,3 \\
\hline ГУ+1 компонент & $65 / 55,08$ & 8,9 \\
\hline
\end{tabular}

У кожному четвертому випадку ГУ асоційована $з$ трьома компонентами МС - АГ, ожиріння, дисліпідемія; у кожному восьмому випадку - 3 чотирма компонентами (АГ, ожиріння, дисліпідемія, ПГГ). Вірогідність діагностики одразу декількох компонентів МС знижується в 2 рази по мірі включення до діагностичного пошуку ще одного додаткового компоненту. Встановлено, що за наявності двох компонентів МС (ожиріння + дисліпідемія, ГУ + дисліпідемія, ожиріння-ПТГ) вірогідність діагностики гіперінсулінемії зростає до 75 \%. За наявності трьох компонентів МС (ожиріння + дисліпідемія + ГУ; ожиріння + дисліпідемія + ПТГ) гіперінсулінемія $є$ практично облігатною ознакою (у 90 \% випадків).

Обговорення результатів. Повний або відносно повний $\mathrm{MC}$, за якого діагностують максимальну кількість складових, зустрічається у $2 \%$ населення [3]. На перший погляд, незначна частота МС у популяції виглядає більш разючою при аналізі їі частоти серед загалу з ПТГ. Встановлено, що кожний четвертий обстежений випадкової популяційної вибірки, у якого при обстеженні було діагностовано ПТГ і ЦД 2 типу, має «повний» МС. Тобто вірогідність діагностики МС у осіб з ПГГ зростає в 10 разів порівняно 3 вірогідністю його діагностики в популяції.

Розрахунки показують, що якщо верифікацію «повного» МС не обмежувати обов'язковим включенням до його складу ГУ, частота діагностики у одного представника випадкової популяційної вибірки квартету симптомів (ожиріння $+\mathrm{A} \Gamma+$ дисліпідемія + гіперінсулінемія) зростає в два рази і складає вже 4 \% від усієї випадкової популяційної вибірки. За цієї умови у кожного другого представника випадкової популяційної вибірки 3 ПТГ діагностують «повний» $\mathrm{MC}$.

Незважаючи на те, що в епідеміологічних дослідженнях встановлено зв'язок ГУ з основними компонентами МС, ГУ можна розглядати як один з основних компонентів МС у популяції за певних умов. Під ГУ, як компонент МС, у популяції, слід розуміти ГУ, діагностика якої здійснюється у відповідності до популяційних норм концентрації СК у крові (<360 мкмоль/л для жінок і $<420$ мкмоль/л для чоловіків) [21]. Тоді як у рекомендаціях представлено жорсткі критерії діагностики ГУ, які орієнтовані на діагностику подагри, за якої концентрація СК у крові патологічно висока [22]. Проведене дослідження показало, що патологічно високу ГУ діагностують у випадковій популяційній вибірці значно рідше $(6,4$ \%), ніж ГУ за популяційними нормативами (16,2 \%). Розглядати ГУ як компонент МС у популяції з більшою впевненістю можна лише у випадку, коли ПГГ представлені у вигляді ПТГ або ЦД 2 типу легкої форми. За гіперглікемії і глюкозурії, навіть якщо у особи присутні інші компоненти МС, діагностувати ГУ досить складно. Проспективні дослідження [23, 24] показали, що наявність подагри підвищує ризик ЦД 2 типу, у той час як наявність ЦД 2 типу знижує ризик подагри. Можливо такий феномен можна пояснити підвищенням екскреції уратів у хворих на ЏД 2 типу за глюкозурії [25]. У жодного 3 п'яти обстежених хворих на Џ 2 типу середньої тяжкості не було діагностовано ГУ, а невисокий рівень урикемії супроводжувався надмірною (> 6,6 ммоль/добу) урикурією. 
Таким чином, при обстежені випадкової популяційної вибірки ГУ діагностовано у 16,2% осіб. Встановлено, що у осіб з ГУ значного підвищується вірогідність діагностики МС. Практично кожний другий випадок ГУ у випадковій популяційній вибірці асоціюється як мінімум ще 3 двома компонентами MC, у кожному четвертому випадку - 3 трьома компонентами, у кожному восьмому випадку - 3 чотирма компонентами. Кожний четвертий у випадковій популяційній вибірці, у якого було діагностовано ПТГ і ЦД 2 типу, має «повний» МС; вірогідність діагностики МС у осіб з ПГГ зростає в 10 раз порівняно з випадковою популяційною вибіркою.

\section{Висновки:}

1. Гіперурикемію діагностовано у $16,2 \%$ осіб у випадковій статистичній вибірці.

2. Встановлено, що в осіб з гіперурикемією підвищується вірогідність діагностики порушень глюкозного гомеостазу в цілому в 5,1 разу, ЦД 2 типу в 3,7 разу, ожиріння в 2,9 разу, АГ в 2,3 разу і дисліпідемії в 1,7 разу, відповідно.

3. Визначено, що практично кожний другий випадок гіперурикемії у випадковій популяційній вибірці асоціюється як мінімум 3 двома компонентами МС (АГ + ожиріння), у кожному четвертому випадку - 3 трьома компонентами (АГ + ожиріння + дисліпідемія), у кожному восьмому випадку - 3 чотирма компонентами (АГ + ожиріння + дисліпідемія + порушення глюкозного гомеостазу).

4. Кожний четвертий представник випадкової популяційної вибірки, у якого було діагностовано порушення толерантності до глюкози і ЦД 2 типу, має «повний» МС; вірогідність діагностики МС у осіб 3 порушеннями глюкозного гомеостазу зростає в 10 раз порівняно з випадковою популяційною вибіркою.

5. Якщо верифікацію «повного» МС не обмежувати обов'язковим включенням до його складу гіперурикемії як компонента, частота діагностики квартету симптомів (ожиріння $+\mathrm{A} \Gamma+$ дисліпідемія + гіперінсулінемія) зростає в два рази і складає вже $4 \%$ від усієї випадкової популяційної вибірки. За цієї умови в кожного другого представника випадкової популяційної вибірки з порушеннями толерантності до глюкози діагностують «повний» МС.

\section{References:}

1. Alberti KG, Zimmet PZ. Definition, diagnosis and classification of diabetes mellitus and its complications. Part 1: diagnosis and classification of diabetes mellitus provisional report of a WHO consultation. Diabet Med. 1998; Jul, 13; 15(7):539-53. doi: 10.1002/(SICI)1096-9136(199807)15:7<539::AIDDIA668>3.0.CO;2-S.

2. Grundy SM, Brewer HJ, Cleeman JI, Smith SC, Lenfant C. Definition of metabolic syndrome: Report of the National Heart, Lung, and Blood Institute/American Heart Association conference on scientific issues related to definition. Circulation. 2004; Feb, 1; 109:433-8. doi: 10.1161/01.ATV.0000111245. 75752.C6.

3. Alberti KG, Zimmet PZ, Shaw J. Metabolic syndrome--a new world-wide definition. A consensus statement from the International Diabetes Federation. Diabet Med. 2006; April, 20; 23:469-80. doi: 10.1111/j.1464-5491.2006.01858.x.

4. Sun HL, Pei D, Lue KH, Chen YL. Uric acid levels can predict metabolic syndrome and hypertension in adolescents: a 10-year longitudinal study. PLoS One. 2015; Nov, 30; 10(11):e0143786. doi: 10.1371/journal.pone.0143786.

5. Tang L, Kubota M, Nagai A, Mamemoto K, Tokuda M. Hyperurikemia in obese children and adolescents: the relationship with metabolic syndrome. Pediatr Rep. 2010; May, 5;2(1):e12. doi: 10.4081/pr.2010.e12.

6. Culleton BF, Larson MG, Kannel WB, Levy D. Serum uric acid and risk for cardiovascular disease and death: the Framingham Heart Study Ann Intern Med 1999; Jul, 6;131(1):7-13. doi: 10.7326/0003-4819-131-1199907060-00003.

7. Lanaspa C, Jensen MA, Tolan DR, Sánchez-Lozada LG, Johnson RJ. Uric Acid as a Cause of the Metabolic Syndrome. Contrib Nephrol. 2018; Jan, 23; 192:88102. doi: 10.1159/000484283.

8. Choi HK, Ford ES, Li CY, et al. Prevalence of the Metabolic syndrome in patients with gout: The Third National Health and Nutrition Examination Survey. Arthr Rheum. 2007; Jan, 31; 57(1):109-15. doi: 10.1002/art.22466.

9. Yoo TW, Sung KC, Shin HS, et al. Relationship between serum uric acid concentration and insulin resistance and metabolic syndrome. Circ J. 2005; Jul, 25; 69:928-33. doi: https://doi.org/ 10.1253/ circj.69.928.

10. Johnson RJ, Nakagawa T, Sanchez-Lozada LG, Shafiu M, Sundaram S, Le M, Ishimoto T, Sautin YY, et al. Sugar, uric acid, and the etiology of diabetes and obesity. Diabetes. 2013; Oct, 10; 62(10):3307-15. doi: $10.2337 / \mathrm{db} 12-1814$

11. Lima WG, Martins-Santos ME, Chaves VE. Uric acid as a modulator of glucose and lipid metabolism. Biochimie. 2015; Jun, 29; 116:17-23. doi: 10.1016/j.biochi.2015.06.025.

12. Keitel R, Keitel W. Therapy of gout. Management of an acute attack. MMW Fortschr. Med. 2000; Mar, 1; 142(12):48-50. PMID: 10804720.

13. Alberti KG, Eckel RH, Grundy SM, Zimmet PZ, Cleeman JI, Donato KA, et al. Harmonizing the metabolic syndrome: a joint interim statement of the International Diabetes Federation Task Force on Epidemiology and Prevention; National Heart, Lung, and Blood Institute; American Heart Association; World Heart Federation; International Atherosclerosis Society; and International Association for the Study of Obesity. Circulation. 2009; Oct, 5; 120:1640-45. doi: 10.1161/CIRCULATIONAHA.109.192644.

14. Rajeev C, Madhu SV, Makkar BM, Sujoy G, Banshi S, Sanjay K. RSSDI-ESI Clinical Practice Recommendations for the Management of Type 2 Diabetes Mellitus 2020, On behalf of the RSSDI-ESI Consensus Group Indian. J. Endocrinol. Metab. 2020; Apr, 20; 24(1):1-122. doi: 10.4103/ijem.IJEM_225_20. 
15. HOMA Calculator. The Oxford Centre for Diabetes. Endocrinilogy and Metabolism [Internet]. 2019; Nov, 19. www.dtu.ox.ac.uk/homacalculator/ index.php.

16. Klimov AN, Nikul'cheva YuG. Obmen lipidov i lipoproteidov i ikh narusheniya. SPb.; 1999. P.505.

17.2018 ESC/ESH Guidelines for the management of arterial hypertension. Rev Esp Cardiol (Engl Ed). 2019; Feb, 15; 72(2):160. doi: 10.1016/j.rec.2018.12.004.

18. Ali N, Perveen R, Rahman S, Mahmood S, Rahman S, et al. Prevalence of hyperuricemia and the relationship between serum uric acid and obesity: A study on Bangladeshi adults. PLoS One. 2018; Nov, 1; 13(11):e0206850. doi: 10.1371/journal.pone.0206850.

19. Thottam GE, Krasnokutsky S, Pillinger M H. Gout and Metabolic Syndrome: a Tangled Web. Curr Rheumatol Rep. 2017; Aug, 26; 19(10):60. doi: 10.1007/s1 1926-017-0688-y.

20. Krishnan E, Pandya BJ, Chung L, Hariri A, Dabbous O. Hyperuricemia in young adults and risk of insulin resistance, prediabetes, and diabetes: a 15-year followup study. Am J Epidemiol. 2012; Jul, 2; 176(2):10816. doi: 10.1093/aje/kws002.

21. Chizyński K, Rózycka M. Hyperuricemia. Polsky Merkuriousz Lekarski. 2005; Nov, 17; 19(113):693-6. PMID: 16498814.

22. Richette P, Doherty M, Pascual E, Barskova V, et al. 2016 updated EULAR evidence-based recommendations for the management of gout. Ann Rheum Dis. 2017; Jul, 25; 76(1):29-42. doi: 10.1136/annrheumdis2016-209707.

23. Rho YH, Lu N, Peloquin CE, et al. Independent impact of gout on the risk of diabetes mellitus among women and men: a population-based, BMI-matched cohort study. Ann Rheum Dis. 2016; Oct, 2; 75(1):915. doi: 10.1136/annrheumdis-2014-205827.

24. Pan A, Teng GG, Yuan JM, et al. Bidirectional Association between Diabetes and Gout: the Singapore Chinese Health Study. Sci Rep. 2016; May, 10; 6:25766. doi: 10.1038/srep25766.

25. Lytvyn Y, Škrtić M, Yang GK, et al. Glycosuriamediated urinary uric acid excretion in patients with uncomplicated type 1 diabetes mellitus. Am J. Physiol. Renal. Physiol. 2015; Jan, 15; 308(2):77-83. doi: 10.1152/ajprenal.00555.2014.

\section{УДК 616-008.9:616.379-008.64:616.72-002.78 \\ К ВОПРОСУ ОЦЕНКИ ЗНАЧЕНИЯ ГИПЕР- УРИКЕМИИ С ПОЗИЦИЙ ПРИНАДЛЕЖНОСТИ К МЕТАБОЛИЧЕСКОМУ СИНДРОМУ}

\author{
А.А. Черняева ${ }^{1,2}$ \\ ${ }^{1}$ Государственное учреждение «Институт проблем \\ эндокринной патологии им. В. Я. Данилевского Наци- \\ ональной академии медицинских наук Украиныл», \\ отдел клинической эндокринологии, \\ 2. Харьков, Украина; \\ ${ }^{2}$ Харьковская медииинская академия последипломно- \\ го образования Министерства здравоохранения \\ Украины, кафедра эндокринологии и детской \\ эндокринологии, г. Харьков, Украина,
}

ORCID ID: 0000-0002-2812-3323,

e-mail: annakholodnaja2008@gmail.com

Резюме. Цели: анализ связи гиперурикемии (ГУ) с компонентами метаболического синдрома (MC) в случайной популяционной выборке.

Методы. Группа из 727 обследованных сформирована методом случайной выборки из числа рабочих и служащих промышленного предприятия. Возраст обследованных от 18 до 65 лет. Проводили диагностику МС и нарушений глюкозного гомеостаза (НГГ), клинико-биохимическое исследование. Инсулинорезистентность оценивали по индексу HOMA2_IR. Статистический анализ проводили с использованием "Statgraphics Plus for Windows 3.0».

Результаты. ГУ диагностирован у 16,2 \% человек. Установлено, что в лиц с ГУ повышается вероятность диагностики НГГ в 5,1 раза, сахарного диабета (СД) 2 типа в 3,7 раза, ожирения в 2,9 раза, артериальной гипертензии (АГ) в 2,3 раза и дислипидемии в 1,7 раза, соответственно. Выявлено, что практически каждый 2-й случай ГУ в случайной популяционной выборке ассоциируется как минимум еще с 2-мя компонентами МС (АГ + ожирение), в каждом 4-м случае - с 3-мя компонентами (АГ + ожирение + дислипидемия), в каждом 8-м случае - с 4-мя компонентами (АГ + ожирение + дислипидемия + ПГГ). Установлено, что каждый 4-й представитель случайной популяционной выборки с нарушением толерантности к глюкозе (НТГ) и СД 2 типа, имеет «полный» МС; вероятность диагностики МС у лиц с НГГ возрастает в 10 раз по сравнению с популяцией.

Выводы. Если верификацию «полного» МС не ограничивать обязательным включением в его состав ГУ, частота диагностики у одного представителя случайной популяционной выборки квартета симптомов (ожирение + АГ + дислипидемия + гиперинсулинемия) возрастает вдвое и составляет уже 4\% от всей выборки. При этом условии у каждого 2-го представителя вышеупомянутой выборки с НТГ диагностируют «полный» МС.

Ключевые слова: гиперурикемия, метаболический синдром, нарушения глюкозного гомеостаза, сахарный диабет 2 типа.

\section{UDC 616-008.9:616.379-008.64:616.72-002.78 \\ ON THE EVALUATION OF THE SIGNIFICANCE OF HYPERURICEMIA FROM THE POSITION OF BELONGING TO THE METABOLIC SYNDROME}
A.A. Cherniaieva ${ }^{1,2}$
${ }^{1}$ State Institution «V. Danilevsky Institute for endocrine pathology problems National Academy of Medical scienc- es of Ukraine», Department of Clinical Endocrinology, Kharkiv, Ukraine,
${ }^{2}$ Kharkiv Medical Academy of Postgraduate Education of the Ministry of Health of Ukraine, Department of
Endocrinology and Pediatric Endocrinology,
Kharkiv, Ukraine,
ORCID ID: 0000-0002-2812-3323, 
e-mail: annakholodnaja2008@gmail.com

Abstract. Purposes: analysis of the relationship of hyperuricemia with the components of the metabolic syndrome in a random population sample.

Methods. The group of subjects $(n=727)$ was formed according to the generally accepted epidemiological approaches by the method of random sampling from among the workers and employees of the industrial enterprise Private joint-stock company «Novokramatorsky machine-building plant». The age of the subjects ranged from 18 to 65 years, the average $(38.13 \pm 5.1)$ years. The presence and degree of obesity were determined by body mass index, according to WHO criteria 2000. Determination of waist circumference $(\mathrm{cm})$ was performed in the vertical position of the patient in the middle of the distance between the lower edge of the chest and the crest of the Ilium along the mid-inguinal line. Metabolic syndrome was diagnosed according to a joint intermediate statement IDF, NHLBI, AHA, WHF, IAS and IASO. Diagnosis of disorders of glucose homeostasis was carried out according to the recommendations of ADA, 2012. Conducted clinical and biochemical researches (anthropometric parameters and blood pressure, immunoreactive insulin levels, lipid profile, uric acid concentration in the blood), the degree of severity of insulin indifference HOMA2 IR. Statistical analysis was performed using "Statgraphics Plus for Windows 3.0". The normality of the distribution of variables was determined using the Shapiro-Wilk test. The Wilcoxon-Mann-Whitney test was used to compare paired variables in groups with normal distribution of variables. The "Chi-square" $(\chi 2)$ criterion with Yates correction was used for statistical estimation of differences between the empirical and theoretical frequencies of the variation series. Regression analysis was used to identify the relationship between clinical, bio- chemical, and hormonal indicators and the normal distribution of variables.

Results. Hyperuricemia was diagnosed in $16.2 \%$ of people. It has been established that in people with hyperuricemia the probability of diagnosis of disorders of glucose homeostasis increases by 5.1 times, diabetes mellitus by 3.7 times, obesity by 2.9 times, hypertension high blood pressure by 2.3 times and dyslipidemia by 1.7 times, respectively. It is determined that almost every second case of hyperuricemia in a random population sample is associated with at least two more components of metabolic syndrome (high blood pressure + obesity), in every fourth case - with three components (high blood pressure + obesity + dyslipidemia), in every eighth case with four components (hypertension + obesity + dyslipidemia + disorders of glucose homeostasis). It was found that in every fourth representative of the random population sample, who was diagnosed with impaired glucose tolerance and type 2 diabetes mellitus, has a "complete" metabolic syndrome; the probability of diagnosing metabolic syndrome in people with disorders of glucose homeostasis increases 10 times compared with the population.

Conclusions. If the verification of "complete" metabolic syndrome is not limited to the mandatory inclusion of hyperuricemia, the frequency of diagnosis in one member of a random population sample of the quartet of symptoms (obesity + high blood pressure + dyslipidemia + hyperinsulinemia) doubles and is already $4 \%$ of the total random population sample. Under this condition, every second representative of the random population sample of impaired glucose tolerance is diagnosed with "complete" metabolic syndrome.

Keywords: hyperuricemia, metabolic syndrome, impaired glucose homeostasis, type 2 diabetes.

Стаття надійшла в редакцію 11.08.2020 р. 